\title{
Does ethnic ancestry play a role in smoking?
}

\section{ELISA S.T. DE SOUZA ${ }^{1}$, LUIZA F. DE ARAÚJO ${ }^{2}$, DAYSE O. DE ALENCAR ${ }^{3}$, SIDNEY E.B. DOS SANTOS ${ }^{3}$, WILSON A. SILVA Jr , CRISTIANE A. FERREIRA ${ }^{2}$ and JOSÉ BADDINI-MARTINEZ ${ }^{1}$}

\author{
${ }^{1}$ Faculdade de Medicina de Ribeirão Preto, Universidade de São Paulo, Departamento \\ de Clínica Médica, Avenida Bandeirantes, 3900, 14048-900 Ribeirão Preto, SP, Brasil \\ ${ }^{2}$ Faculdade de Medicina de Ribeirão Preto, Universidade de São Paulo, Departamento \\ de Genética, Centro de Genômica Médica e Hemocentro de Ribeirão Preto, \\ Rua Tenente Catão Roxo, 2501, 14051-140 Ribeirão Preto, SP, Brasil \\ ${ }^{3}$ Departamento de Patologia, Universidade Federal do Pará, Laboratório de Genética \\ Médica e Humana, Rua Augusto Correa, 1, 66075-110 Belém, PA, Brasil
}

Manuscript received on April 24, 2014; accepted for publication on September 8, 2014

\begin{abstract}
The higher proportion of smokers among Black people in Brazil has been attributed to socioeconomic disparities, but genetic factors could also contribute for this finding. This study aimed at investigating associations between smoking status with genetically defined ethnic ancestry and socioeconomic features in Brazilians. Blood samples were collected from 448 volunteers (66.7\% male; age: $37.1 \pm 11.4$ years) classified as current smokers (CS: 60.9\%), former smokers (FS: $8.9 \%$ ) and never smokers (NS: 30.1\%). Individual interethnic admixtures were determined using a 48 insertion-deletion polymorphisms ancestryinformative-marker panel. CS showed a lower amount of European ancestry than NS $(0.837 \pm 0.243 \mathrm{X}$ $0.883 \pm 0.194, p \leq 0.05)$ and FS $(0.837 \pm 0.243 \times 0.864 \pm 0.230, p \leq 0.05)$, and a higher proportion of African Sub-Saharan ancestry than FS $(0.128 \pm 0.222 \times 0.07 \pm 0.174, \mathrm{p} \leq 0.05)$ and NS $(0.128 \pm 0.222 \times 0.085 \pm 0.178$, $\mathrm{p} \leq 0.05)$. NS reported a higher number of years in school than CS $(11.2 \pm 3.7 \times 8.9 \pm 3.8, p \leq 0.001)$. CS were less common in economic Class A (30\%) and more common in Class B (56.8\%). In multivariate analysis, only lower number of school years and lower economic class were associated with higher chances for CS. The use of genetic molecular markers for characterizing ethnic background confirmed that socioeconomic disparities are the main determinants of higher smoking rates among Blacks in Brazil.
\end{abstract}

Key words: smoking, ethnicity and health, genetics, CYP2A6.

\section{INTRODUCTION}

Ethnic differences in the prevalence of smoking have been commonly recognized in several countries (Trinidad et al. 2009, 2011, Kahende et al. 2011). For instance, non Hispanic White Americans are more likely to be current smokers

Correspondence to: José Baddini-Martinez

E-mail: baddini@fmrp.usp.br and smoke more heavily than Blacks and Hispanic Whites (Ward et al. 2002, Shavers et al. 2006). An opposite situation has been described in Brazil, where the proportion of current smokers in Whites is described as $15.3 \%$ and $19 \%$ among Blacks and Intermediate people (IBGE 2009, INCA 2011).

The higher proportion of smokers among Black and Intermediate people in Brazil has been 
attributed to socioeconomic disparities, but this interpretation may be mistaken, since genetic factors could theoretically contribute towards the finding (IBGE 2009, INCA 2011).

Besides, all published studies dealing with smoking and ethnicity have been based on volunteers' self-classification, instead of using precise genetic markers. This may become a major issue in highly admixture populations.

Brazilians are one of the most mixed populations in the world due to centuries of miscegenation especially between three groups, Europeans, Africans and Amerindians. Ethnic classifications based on geographic origin or physical features are highly misleading in this population (Parra et al. 2003, Pimenta et al. 2006, Santos et al. 2009, Leite et al. 2011).

A set of 48 ancestry-informative insertiondeletion polymorphisms (INDELs) was developed aiming at measuring the proportions of three different ancestries, sub-Saharan African, European, and Amerindian, in mixed populations (Santos et al. 2010). This panel allowed accurate estimation of individual and global interethnic admixture relative to the ancestry of Brazilians from three regions of the country.

Cytochrome P450 2A6 (CYP2A6) is the enzyme primarily responsible for metabolizing nicotine to cotinine and related products (Benowitz et al. 2009, Raunio and Rahnasto-Rilla 2012). This gene is highly polymorphic, specially in the regulatory regions, and the potential role of its variants in smoking behavior is a subject of continuous attention (Bloom et al. 2011, Rodriguez et al. 2011, Verde et al. 2011, Tang et al. 2012, Zhu et al. 2013). The *1A allele is usually considered the wild type, corresponding to normal enzymatic activity (Malaiyandi et al. 2005). The $* 1 B$ allele exhibits 58 base pairs derived from the CYP2A 7 gene in a 3' region, and it has been associated with faster in vivo nicotine metabolism (Goodz and Tyndale 2002, Mwenifumbo et al. 2008).
The levels of nicotine metabolism may influence smoking phenotypes (Munafó and Johnstone 2008, Mwenifumbo and Tyndale 2007). The frequencies of the *1B allele varies widely among ethnical groups, from $30 \%$ in Caucasians to $55 \%$ in Canadian Amerindians (Munafó and Johnstone 2008).

Only one study has been performed so far dealing with the potential influence of CYP2A6 in smoking status among Brazilians. Vasconcelos et al. (2005) found significant lower odds ratio (OR) for being a smoker versus non smoker for genotypes including the allele CYP2A6*1B as compared to the wild type homozygous (CYP2A6*1A/*1A) in White and Intermediate people. In contrast, the corresponding $\mathrm{OR}$ in Blacks were significantly elevated. These results suggested that among Brazilians the polymorphism CYP2A6*1B is associated with protection against nicotine dependence in White and Intermediate people but not in Blacks.

The objective of this study was to investigate potential associations between smoking status with genetically defined ethnic ancestry, CYP2A6*1B polymorphism, and socioeconomic features in Brazilians.

\section{METHODS}

Blood samples were collected from 448 blood donors at the Regional Blood Center of Ribeirão Preto in São Paulo, Brazil. As all volunteers were blood donors, subjects under the age of 18 , suffering from chronic illnesses, and referring a history of alcoholism or illicit drug abuse were not included.

The volunteers were invited to fill out a survey including questions about their gender, age, smoking history and the number of years expended in school. The subjects also answered questions dealing with their socio-economic conditions, based on criteria of the Brazilian Association of Research Companies (ABEP 2014). The so called Brazil economic criteria distinguish seven economic classes: $A_{1}, A_{2}, B_{1}, B_{2}, C_{1}, C_{2}, E$ and $F$. As the distribution of the results was uneven, a distinct 
approach was employed in this study. Classes $A_{1}$ and $A_{2}$ were merged in a Class $A$. Classes $B_{1}$ and $B_{2}$ were merged in a Class B, while Classes $\mathrm{C} 1, \mathrm{C} 2$, E and $\mathrm{F}$ were merged in a Class $\mathrm{C}$.

The volunteers were classified according to their smoking status in one of three categories: current smokers (CS), subjects who had smoked non less than one package of cigarettes in their lives and at least one cigarette in the past week; former smokers (FS), subjects who had smoked non less than one pack of cigarettes throughout life and had not smoked any cigarette for at least six months; never smokers (NS), subjects who had never smoked or had smoked less than a pack of cigarettes in their lives. Smoking status of volunteers was checked by measurement of exhaled carbon monoxide levels.

Total DNA was extracted from blood samples using the Wizard Genomic DNA Purification Kit (Promega, Madison, USA). Individual interethnic admixtures were determined using a panel of 48-INDELs ancestry-informative-marker (AIM) panel, previously applied for Brazilian population analysis. Genotyping of the 48 INDEL markers in this study followed the methodology described by Santos et al. (2010). This approach permitted estimates of individual and global admixture relative to three ancestry groups: European, African Sub-Saharan and Amerindian.

CYP2A6 gene variants were analyzed employing PCR amplification with the primers R2 (5'AAAATGGGCATGAACGCCC-3') and 8s (5'CACCGAAGTGTACCCTATGCTG-3'), based on previous published study (Nakajima et al. 2001). The final product was submitted to double digestion with the enzymes BstUI and BSU36I (New EnglandBiolabs, Ipswich, USA) and ran in a vertical field electrophoresis $6 \%$ polyacrylamide gel, that was stained with silver nitrate. The analysis of fragments enabled the identification of the CYP2A6 alleles $* 1 \mathrm{~A}, * 1 \mathrm{~B}$ and $* 4$. This methodology did not allow an adequate characterization of genotypes in all cases and these alleles were then classified as not identified (NI). Since CYP2A6*1B was of main interest in this study, statistical analysis was performed with volunteers arranged in three groups based on the number of alleles for this polymorphism: none, one or two.

Results are shown as frequencies, means and standard deviations. Associations between the three groups and categorical variables were investigated by chi-square tests followed by comparison of proportions tests with Bonferroni's correction when necessary. Numerical variables were compared by analysis of variance on ranks, followed by Dunn's post test when necessary. In addition, a multivariate binary logistic regression model was constructed employing gender, age, European and African ancestry, CYP2A6 polymorphisms *1B and No*1B, years in school and economic status as independent variables. The dependent variable in the model was CS in opposition to FS and NS. The levels of statistical significance were always set at $\mathrm{p} \leq 0.05$ and all analyses were performed using the SPSS Statistics Software v.20.

The present investigation was approved by the Ethics Committee on Human Research of the Clinics Hospital of the Medical School of Ribeirão Preto, and all volunteers signed informed consents.

\section{RESULTS}

A total of 448 subjects were included in the study, most of them male (66.7\%). Most of the individuals, $273(60.9 \%)$ were classified either as CS, 40 (8.9\%) as FS and NS 135 (30.1\%). Among CS the average age of smoking onset was $16.2 \pm 4.4$ years, the mean

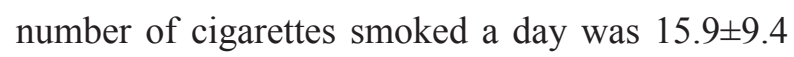
units, and the mean score for the Fagerström Test for Nicotine Dependence was 3.7 \pm 2.4 . The CS mean number of smoked pack.years was $17.3 \pm 0.47$. The mean age of NS (34.6 \pm 11.4 years) was significantly lower than that of CS and FS (37.6 \pm 11.0 and $42.2 \pm 11.7$ years respectively; Table I).

The frequencies of CYP2A6 alleles observed were: *1A/*1A:178(39.7\%); *1A/*1B:130(29\%); 
TABLE I

Univariate comparisons of parameters with subjects classified according to smoking status.

\begin{tabular}{|c|c|c|c|c|}
\hline & & $\begin{array}{c}\text { Current } \\
\text { smokers (CS) } \\
(n=273)\end{array}$ & $\begin{array}{c}\text { Former } \\
\text { smokers (FS) } \\
(n=40)\end{array}$ & $\begin{array}{c}\text { Never } \\
\text { mokers (NS) } \\
(\mathbf{n}=\mathbf{1 3 5})\end{array}$ \\
\hline \multirow{2}{*}{ Gender } & Male & $189(42.2 \%)$ & $33(7.4 \%)$ & $77(17.2 \%)$ \\
\hline & Female & $84(18.8 \%)$ & $7(1.6 \%)$ & $58(12.9 \%)$ \\
\hline \multicolumn{2}{|c|}{ Age (years) } & $37.6 \pm 11.0$ & $42.2 \pm 11.7$ & $34.6 \pm 11.4^{+}$ \\
\hline \multirow{3}{*}{ Ethnic ancestry } & European & $0.837 \pm 0.243$ & $0.864 \pm 0.230$ & $0.883 \pm 0.194^{++}$ \\
\hline & African & $0.128 \pm 0.222^{\S}$ & $0.070 \pm 0.174$ & $0.085 \pm 0.178$ \\
\hline & Amerindian & $0.034 \pm 0.070$ & $0.065 \pm 0.137$ & $0.032 \pm 0.066$ \\
\hline \multirow{3}{*}{ CYP2A6 polymorphisms } & No*1B/No*1B & $166(60.8 \%)$ & $27(67.5 \%)$ & $81(60.0 \%)$ \\
\hline & $* 1 \mathrm{~B} / \mathrm{No}^{*} 1 \mathrm{~B}$ & $84(30.8 \%)$ & $9(22.5 \%)$ & $41(30.4 \%)$ \\
\hline & $* 1 \mathrm{~B} / * 1 \mathrm{~B}$ & $23(8.4 \%)$ & $4(10.0 \%)$ & $13(9.6 \%)$ \\
\hline \multicolumn{2}{|c|}{ School years } & $8.9 \pm 3.8^{\S \S}$ & $9.8 \pm 3.5$ & $11.2 \pm 3.7$ \\
\hline \multirow{3}{*}{ Economic status } & Class A & $82(30 \%)^{\pi}$ & $23(57.5 \%)$ & $65(48.1 \%)$ \\
\hline & Class B & $155(56.8 \%)^{\text {q⿻ }}$ & $13(32.5 \%)$ & $55(40.7 \%)$ \\
\hline & Class C & $36(13.2 \%)$ & $4(10.0 \%)$ & $15(11.1 \%)$ \\
\hline
\end{tabular}

${ }^{+} \mathrm{p} \leq 0.05$ compared to CS and $\mathrm{p} \leq 0.001$ compared to FS by Dunn's post test. ${ }^{++} \mathrm{p} \leq 0.05$ compared to CS and FS by Dunn's post test. ${ }^{\S} \mathrm{p} \leq 0.05$ compared to FS and NS by Dunn's post test. ${ }^{\S} \mathrm{p} \leq 0.001$ compared to NS by Dunn's post test. " $\mathrm{p} \leq 0.01$ compared to FS and $p \leq 0.001$ compared to NS by comparison of proportions test. ${ }^{\text {IT }} \mathrm{p} \leq 0.001$ compared to FS and $p \leq 0.01$ compared to NS by comparison of proportions test.

*4/*NI:58 (12.9\%); *1B/*1B:40 (8.9\%); *NI/*NI:21 $(4.7 \%) ; * 1 \mathrm{~A} / * 4: 15(3.3) ; * 1 \mathrm{~B} / * 4: 5(1.1 \%) ; * 4 / * 4: 1(0.2 \%)$. The analysis performed with the alleles classified only in two categories, No*1B in opposition to $* 1 \mathrm{~B}$, did not show significant differences in the genotypes between the subjects grouped according to their smoking status.

Current smokers exhibited a significantly lower amount of European ancestry than FS and NS in univariate analysis $(0.837 \pm 0.243 \mathrm{X} 0.864 \pm 0.230$ and $0.883 \pm 0.194$, respectively; Table I). Current smokers also showed a significantly higher amount of African ancestry than FS and NS $(0.128 \pm 0.222$ $\mathrm{X} \quad 0.070 \pm 0.174$ and $0.085 \pm 0.178$, respectively). There were not statistically significant differences regarding the amounts of Amerindian ancestry between groups. The number of years expended in school was also significantly lower in CS comparing with NS (8.9 $\pm 3.8 \times 11.2 \pm 3.7)$. Current smokers showed a significant smaller proportion of subjects within economic Class A in comparison with FS and NS (30\% X 57.5\% and 48.1\%, respectively; Table I). The proportion of CS was also significantly higher than FS and NS into the economic Class B $(56.8 \% \mathrm{X}$ $32.5 \%$ and $40.7 \%$; Table I). There were no significant differences among the proportions of subjects from the three groups within the economic Class $\mathrm{C}$.

When multivariate analysis was performed, only number of school years and economic class were identified as factors significantly associated with smoking status (Table II). In this scenario, the chances of belonging to $\mathrm{CS}$ decreased with higher numbers of school years (OR: 0.89; CI95\%: 0.84-0.94; $\mathrm{p} \leq 0.001)$. In addition, the chances of belonging to CS significantly increased for Class B in relation to Class A (OR: 1.87; CI95\%: 1.20-2.89; $\mathrm{p} \leq 0.01$ ), but not for class C (OR: 1.32 ; CI95\%: $0.67-2.59 ; \mathrm{p}>0.05)$. 
TABLE II

Statistically significant odds ratio for independent variables in multivariate binary logistic regression model with the dependent variables FS and NS versus CS.

\begin{tabular}{c|c|c|c}
\hline & Odds Ratio & p value & $\mathbf{9 5 \% C I}$ \\
\hline Years in school & 0.89 & $<0.001$ & $(0.84-0.94)$ \\
\hline Economic Class & & & \\
\hline Class A & Reference & - & - \\
\hline Class B & 1.87 & $\mathrm{p} \leq 0.01$ & $(1.20-2.89)$ \\
\hline Class C & 1.32 & $\mathrm{p}>0.05$ & $(0.67-2.50)$ \\
\hline
\end{tabular}

FS: former smokers; NS: never-smokers; CS: current smokers.

\section{DISCUSSION}

Smoking is a complex habit that is influenced by environmental and genetic factors (Benowitz 2010). Although several papers have been published in the field, this is the first study that employed molecular techniques to evaluate the potential influence of ancestry background on smoking status. In addition, this is only the second study dealing with CYP2A6 polymorphisms and smoking habits in the Brazilian population.

The present results did not indicate a role for the CYP2A6*1B polymorphism in smoking status of Brazilians. Indeed, this finding was corroborated by additional analysis including corrections for ethnic backgrounds (data not showed).

A higher proportion of African ancestry was observed in CS comparing with FS and NS. The smaller proportion of European ancestry observed in CS comparing with FS and NS should be, most likely, consequence of the latter finding. Although these results alone could suggest a genetic basis for the reports of higher proportion of smokers among Black and Intermediate subjects than in White Brazilians, a multivariate model including all the potential influencing factors excluded this possibility. Number of years expended in school and economic class were the only factors associated with smoking status, both in univariate and multivariate analysis. The small number of subjects included in Class $\mathrm{C}$ should explain the lack of statistical significance in the analysis involving this group. Overall the results strongly suggest that socioeconomic disparities are the real determinants of dissimilarities in smoking status among ethnic groups in Brazil.

A substantial amount of evidence indicates that worldwide poor socioeconomic conditions are associated with tobacco consumption and other health detrimental behaviors as well (Gupta 2006, Harper and Lynch 2007, Margerison-Kilko and Cubbin 2013). The psychological and social determinants of variations in health behaviors have not been precisely identified, but interventions on factors such as control expectations, social networks, neighborhood characteristics, and school context have already been advocated as suitable targets to improve the conducts of socially deprived populations (Weyers et al. 2010).

The high proportion of CS enrolled in the present study does not reflect the real prevalence of smoking in the Brazilian population. There was an active search for including the highest possible number of smokers in this study aiming at performing genetic studies. Unfortunately this approach led to an underrepresentation of nonsmokers in the sample. This selection bias may have influenced the final results of the study.

Another limitation of the present investigation is the relatively small sample size and its convenience nature. Nevertheless, the strategy of interviewing blood donors is justified by the greater facility of obtaining samples for genetic analysis. Moreover, performing molecular genetic studies is laborious and involves substantial costs.

In conclusion, the use of genetic molecular markers for characterizing ethnic background strongly suggest that socioeconomic disparities, but not ethnic ancestry, are the main determinants of higher smoking rates among Blacks in Brazil. Most probably, reduction in smoking, and even in other risk behaviors to health, deeply rests on better education and economic development of people living in disadvantageous conditions (Baum and Fischer 2014). 


\section{RESUMO}

A maior proporção de fumantes entre negros no Brasil tem sido atribuída a desigualdades socioeconômicas, mas fatores genéticos também poderiam contribuir para esse achado. Este estudo visou investigar associações entre status tabágico com ancestralidade definida geneticamente e características socioeconômicas em brasileiros. Amostras de sangue foram colhidas de 448 voluntários (66,7\% homens; idade: 37,1 $\pm 11,4$ anos) classificados como fumantes atuais (FA: 60,9\%), exfumantes (EF:8,9\%) e não fumantes (NF:30,1\%). Misturas éticas individuais foram determinadas empregando-se um painel informativo de ancestralidade composto por 48 polimorfismos de deleções e inserções. FA mostraram menor proporção de ancestralidade europeia do que NF $(0,837 \pm 0,243$ X $0,883 \pm 0,194$; $\mathrm{p} \leq 0,05)$ e $\operatorname{EF}(0,837 \pm 0,243 \times 0,864 \pm 0,230 ; \mathrm{p} \leq 0,05)$, e maior proporção de ancestralidade africana sub-saárica do que $\mathrm{EF}(0,128 \pm 0,222 \times 0,07 \pm 0,174, \mathrm{p} \leq 0,05)$ e $\mathrm{NF}$ $(0,128 \pm 0,222 \times 0,085 \pm 0,178, p \leq 0,05)$. NF informaram maior número de anos de escola do que FA $(11,2 \pm 3,7$ $X 8,9 \pm 3,8 ; \mathrm{p} \leq 0,001)$. FA foram menos comuns na Classe econômica A (30\%) e mais comuns na Classe B (56,8\%). Em análise multivariada, apenas menor número de anos escolares e menor classe econômica estiveram associados com chances maiores para FA. O uso de marcadores de genética molecular para caracterizar o background étnico confirmou que diferenças socioeconômicas são os principais determinantes de maiores taxas de tabagismo entre negros no Brasil.

Palavras-chave: tabagismo, etnicidade e saúde, genética, CYP2A6.

\section{REFERENCES}

ABEP - AsSOCIAC̄̃̃o BRASILEIRA de EMPRESAS DE PESQUISAS 2014. Critério de classificação econômica Brasil. Available from www.abep.org/new/Servicos/Download.aspx?id=07. [Accessed 02/20/2014].

BAUM F AND FISCHER M. 2014. Why behavioural health promotion endures despite its failure to reduce health inequities. Sociol Health Illn 36: 213-225.

BENOwITZ NL. 2010. Nicotine addiction. N Engl J Med 362: 2295-2303.
BENOwitz NL, HuKKANEN J AND JACOB $3^{\text {rd }}$ P. 2009. Nicotine chemistry, metabolism, kinetics and biomarkers. Handb Exp Pharmacol 192: 29-60.

BloOM J, HinRICHS AL, WANG JC, VON WEYMARN LB, Kharasch ED, Bierut LJ, GoATE A AND Murphy SE. 2011. The contribution of common CYP2A6 alleles to variation in nicotine metabolism among EuropeanAmericans. Pharmacogenet Genomics 21: 403-416.

Goodz SD AND TyNDALE RF. 2002. Genotyping human CYPA6 variants. Methods Enzymol 357: 59-69.

GUPTA R. 2006. Smoking, educational status and health inequity in India. Indian J Med Res 124: 15-22.

HARPER S AND LYNCH J. 2007. Trends in socioeconomic inequalities in adult health behaviors among U.S. states, 1990-2004. Public Health Rep 122: 177-189.

IBGE - INSTITUTO BRASILEIRO DE GEOGRAFIA E ESTATÍSTICA. 2009. Pesquisa Nacional por Amostra de Domicílios. Tabagismo 2008. Rio de Janeiro, RJ: Ministério do Planejamento, Orçamento e Gestão, 128 p.

INCA - INSTITUTO NACIONAL DO CÂNCER. 2011. Organização Panamericana da Saúde (OPAS). Pesquisa Especial de Tabagismo, Relatório Brasil. Rio de Janeiro, RJ: Ministério da Saúde, 199 p.

KAHENDE JW, MALARCHER AM, TEPLINSKAYA A AND ASMAN KJ. 2011. Quit attempt correlates among smokers by race/ ethnicity. Int J Environ Res Public Health 8: 3871-3888.

LeITe TK, Fonseca RM, De França NM, PARRa EJ AND PEREIRA RW. 2011. Genomic ancestry, self-reported "color" and quantitative measures of skin pigmentation in Brazilian admixed siblings. PLoS One 11: e27162.

MALAIYANDI V, SElleRs EM AND TYNDALE RF. 2005. Implications of $\mathrm{CYP}_{2} \mathrm{~A}_{6}$ genetic variation for smoking behaviors and nicotine dependence. Clin Pharmacol Ther 77: $145-158$

MARGERISON-KILKo C AND CUBBIN C. 2013. Socioeconomic disparities in tobacco-related health outcomes across racial/ethnic groups in the United States: national health interview survey. Nicotine Tob Res 15: 1161-1165.

MunAFó MR AND JOHnstone EC. 2008. Genes and cigarette smoking. Addiction 103: 893-904.

MWenifumbo JC, LesSOV-SchlagGar CN, ZHOU Q, KRASNOW RE, SWAN GE, BENOWITZ NL AND TyNDALE RF. 2008. Identification of novel CYP2A6*1B variants: the CYP2A6*1B allele is associated with faster in vivo nicotine metabolism. Clin Pharmacol Ther 83: 115-121.

MWENIFUMBO JC AND TYNDALE RF. 2007. Genetic variability in CYP2A6 and the pharmacokinetics of nicotine. Pharmacogenomics 8: 1385-1402.

NAKAJIMA M, KWON JT, TANAKA N, ZENTA T, YAMAMOTO Y YAMAMOTO H, YAMAZAKI H, YAMAMOTO T, KUROWIA Y AND YOKOI T. 2001. Relationship between interindividual differences in nicotine metabolism and CYP2A6 genetic polymorphism in humans. Clin Pharmacol Ther 69: 72-78.

PARRA FC, AMADO RC, LAMBERTUCCI JR, ROCHA J, ANTUNES CM AND PENA SD. 2003. Color and genomic ancestry in Brazilians. Proc Natl Acad Sci USA 100: 177-182. 
Pimenta JR, Zuccherato LW, Debes AA, Maselli L, SOARES RP, MOURA-NETO RS, ROCHA J, BYDLOWSKI SP AND PENA SD. 2006. Color and genomic ancestry in Brazilians: a study with forensic microsatellites. Hum Hered 62: 190-195.

RAUNIO HAND RAHNASTO-RILLA M. 2012. CYP2A6: genetics, structure, regulation, and function. Drug Metabol Drug Interact 27: 73-88.

Rodriguez S, CoOK DG, Gaunt TR, Nightingale CM, WHINCUP PH AND DAY IN. 2011. Combined analysis of CHRNA5, CHRNA3 and CYP2A6 in relation to adolescent smoking behaviour. J Psychopharmacol 25: 915-923.

SANTOS NP ET AL. 2010. Assessing individual interethnic admixture and population substructure using a 48-insertiondeletion (INSEL) ancestry-informative marker (AIM) panel. Hum Mutat 31: 184-190.

SAntos RV, Fry PH, Monteiro S, Maio MC, Rodrigues JC, Bastos-Rodrigues L and Pena SD. 2009. Color, race, and genomic ancestry in Brazil: dialogues between anthropology and genetics. Curr Anthropol 50: 787-819.

SHAVERS VL, FAGAN P, ALEXANDER LA, CLAYTON R, DOUCET J AND BAEZCONDE-GARBANATI L. 2006. Workplace and home smoking restrictions and racial/ethnic variation in the prevalence and intensity of current cigarette smoking among women by poverty status, TUS-CPS 1998-1999 and 2001-2002. J Epidemiol Community Health Suppl 2: 34-43.

TANG DW, Hello B, Mroziewicz M, Fellows LK, TyNdale RF AND DAGHER A. 2012. Genetic variation in CYP2A6 predicts neural reactivity to smoking cues as measured using fMRI. Neuroimage 60: 2136-2143.
Trinidad DR, PÉrez-Stable EJ, Emery SL, White MM, GRANA RA AND MESSER KS. 2009. Intermittent and light daily smoking across racial/ethnic groups in the United States. Nicotine Tob Res 11: 203-210.

Trinidad DR, PÉrez-Stable EJ, White MM, Emery SL AND MESSER K. 2011. A nationwide analysis of US racial/ethnic disparities in smoking behaviors, smoking cessation, and cessation-related factors. Am J Public Health 101: 699-706.

VASCONCELOS GM, StRUChINER CJ AND SUAREZ-KuRTZ G. 2005. CYP2A6 genetic polymorphisms and correlation with smoking status in Brazilians. Pharmacogenomics J 5: $42-48$.

Verde Z, SANTIAGo C AND Rodriguez GonzÁlez-Moro JM. 2011. Smoking genes': a genetic association study. PLoS One 6: e26668.

WARD KD, VANDER Weg MW, Kovach KW, KLesges RC, DEBON MW, HADDOCK CK, TALCOTT GW AND LANDO HA. 2002. Ethnic and gender differences in smoking and smoking cessation in a population of young adult air force recruits. Am J Health Promot 16: 259-266.

Weyers S, Dragano N, Richter M AND Bosma H. 2010. How does socio economic position link to health behaviour? Sociological pathways and perspectives for health promotion. Glob Health Promot 17: 25-33.

ZHU AZ ET AL. 2013. Alaska Native smokers and smokeless tobacco users with slower CYP2A6 activity have lower tobacco consumption, lower tobacco-specific nitrosamine exposure and lower tobacco-specific nitrosamine bioactivation. Carcinogenesis 34: 93-101. 
